\title{
HUBUNGAN ANTARA KONSEP DIRI DENGAN PENYESUAIAN DIRI SISWA KELAS X MADRASAH ALIYAH NEGERI SIDOARJO
}

\author{
Frita Garnis dan Widyastuti \\ Fakultas Psikologi, Universitas Muhammadiyah Sidoarjo \\ Email: fritagarnis@gmail.com, wiwid@umsida.ac.id
}

\begin{abstract}
Abstrak
Siswa yang baru saja memasuki jenjang pendidikan Sekolah Menengah Atas (SMA) atau Madrasah Aliyah (MA) tentunya akan menyesuaikan diri dengan lingkungan dan suasana yang baru. Namun, dalam praktiknya tidak jarang mengalami masalah. Penelitian ini bertujuan untuk mengetahui hubungan antara konsep diri dengan penyesuaian diri pada siswa kelas X Madrasah Aliyah Negeri Sidoarjo. Penelitian ini merupakan penelitian kuantitatif korelasional. Populasi dalam penelitian ini adalah seluruh siswa kelas X Madrasah Aliyah Negeri Sidoarjo yang berjumlah 420 siswa. Sampel dalam penelitian ini sebanyak 191 siswa dengan teknik sampling accidental sampling. Teknik pengumpulan data dalam penelitian ini menggunakan skala konsep diri $(\alpha=0,900)$ dan skala penyesuaian diri $(\alpha=0,882)$. Teknik analisis data menggunakan korelasi product-moment dari Pearson dengan bantuan SPSS 16.0. Hasil analisis data penelitian ini menunjukkan bahwa nilai koefisien korelasi $\left(r_{\mathrm{xy}}\right)=0,725$ dengan signifikansi $0,000<0,05$ yang artinya terdapat hubungan positif yang signifikan antara konsep diri dengan penyesuaian diri pada siswa kelas X Madrasah Aliyah Negeri Sidoarjo. Pengaruh konsep diri terhadapa penyesuaian diri dalam penelitian ini sebesar $57,7 \%$.
\end{abstract}

Kata Kunci : Konsep Diri, Penyesuaian Diri, Siswa MAN Sidoarjo

\section{RELATIONSHIP BETWEEN SELF-CONCEPT AND SELF-ADJUSTMENT AMONG $10^{\text {TH }}$ GRADERS AT MADRASAH ALIYAH NEGERI SIDOARJO}

\begin{abstract}
Students who have just enrolled the Senior High School (SMA) or Madrasah Aliyah (MA) education level will certainly adjust to the new environment and atmosphere. However, in practice it is not uncommon to experience problems. This study aimed to determine the relationship between self-concept and self-adjustment in class X Madrasah Aliyah Negeri Sidoarjo. This study was a correlational quantitative research. The population in this study were all students of class X Madrasah Aliyah Negeri Sidoarjo, totaling 420 students. The sample in this study were 191 students with accidental sampling technique. Data collection techniques in this study used a self-concept scale $(\alpha=0.900)$ and a self-adjustment scale $(\alpha=0.882)$. The data analysis technique used Pearson's product-moment correlation with the help of SPSS 16.0. The results of the data analysis of this study indicate that the value of the correlation coefficient $(r x y)=0.725$ with a significance of $0.000<0.05$, which means that there is a significant positive relationship between self-concept and self-adjustment in class $X$ Madrasah Aliyah Negeri Sidoarjo. The effect of self-concept on self-adjustment in this study was $57.7 \%$.
\end{abstract}

Keywords: Self-Concept, Self-Adjustment, Students of MAN Sidoarjo

92 


\section{Pendahuluan}

Satu masa transisi dalam rentang kehidupan manusia, yang menjembatani masa kanak-kanak dengan masa dewasa adalah masa remaja (Santrock, 2012). Secara umum, masa remaja dibagi menjadi tiga bagian, bagian kedua dari masa remaja adalah masa remaja pertengahan (15-18 tahun). Konopka ( dalam Agustiani, 2009) mengatakan bahwa masa remaja pertengahan ditunjukkan melalui perkembangan kemampuan berpikir kreatif. Mulai belajar mengendalikan impulsivitas, mengembangkan kematangan tingkah laku, dan membuat keputusan awal yang berkaitan dengan tujuan vokasional yang ingin dicapainya merupakan perkembangan remaja pada masa ini. Selain itu, penerimaan dari lawan jenis menjadi penting bagi remaja (Agustiani, 2009).

Remaja Indonesia yang berusia berkisar antara 15-19 tahun biasanya memasuki bangku SMA/MA (Kuswono, 2013).

Madrasah Aliyah (MA) adalah jenjang pendidikan menengah pada pendidikan formal di Indonesia yang setara dengan Sekolah Menengah Atas (SMA) dengan pengelolaannya dilakukan oleh Kementrian Agama ("Madrasah Aliyah," 2018). Pendidikan Madrasah Aliyah ditempuh dalam waktu 3 tahun, mulai dari kelas 10 hingga kelas 12 ("Madrasah Aliyah," 2018). Remaja yang baru memasuki masa pendidikan Sekolah Menengah Atas (SMA) atau Madrasah Aliyah (MA) akan melakukan penyesuaian diri dengan lingkungan dan suasana yang baru.

Schneiders menggambarkan penyesuasian diri sebagai suatu proses usaha individu yang mencakup respon mental dan tingkah laku, hingga mampu menangani keperluan, ketegangan, frustasi serta konflik yang terasa dalam diri (Agustiani, 2009). Usaha ini, digunakan untuk mendapatkan keharmonisan dan keselarasan antara tuntutan dalam diri dengan apa yang diharapkan oleh lingkungan. Remaja yang memiliki kemauan untuk belajar bereaksi terhadap dirinya dan lingkungan dengan cara yang matang, bermanfaat, efisien, dan memuaskan, serta dapat menyelesaikan konflik, frustasi, maupun kesulitan pribadi dan sosial yang dihadapi tanpa mengalami gangguan tingkah laku meskipun memiliki keterbatasan pada dirinya, merupakan orang yang mampu melakukan penyesuaian diri dengan baik.

Penyesuaian diri bersifat relatif, artinya harus dinilai dan dievaluasi sesuai dengan kapasitas individu untuk memenuhi tuntutan terhadap dirinya. Sedangkan kapasitas ini berbeda-beda tergantung pada kepribadian dan tahap perkembangan individu. Oleh karena itu Schneiders membagi penyesuasian diri ke dalam beberapa kategori, diantaranya pembagian menurut konteks situasional atas respon yang dimunculkan individu (Agustiani, 2009)

Penyesuaian diri ini dialami oleh setiap orang yang berada pada tempat, situasi, dan status yang baru untuknya. Penyesuaian diri siswa yang rendah dapat menimbulkan, frustasi, membolos, datang terlambat ke sekolah, meninggalkan kelas pada saat jam pelajaran berlangsung dan tidak menggunakan atribut sesuai dengan ketentuan sekolah, jarang dan bahkan tidak mengikuti ekstrakurikuler di sekolah, memiliki permasalahan internal dengan guru mata pelajaran tertentu, merasa tidak nyaman karena mendapat ancaman dari teman di sekolah, antisosial, tidak mengumpulkan tugas mata pelajaran tertentu, tidak nyaman dengan jurusan yang telah dipilih dan ingin pindah ke sekolah lain ( $R$ \& Christiana, 2015). Siswa yang mulai memasuki jenjang sekolah baru akan mengalami permasalahan penyesuaian diri. Munculnya gejala dapat dilihat dari 6 bulan pertama pada saat meninggalkan rumah, gangguan penyesuaian pada siswa dapat dikenali dari gejala emosional atau perilaku awal masuk sekolah yang biasa terjadi dalam tiga bulan onset stressor, serta saat stresor berhenti. (Kaplan, Sadock, \& Grebb, 1997). 
Permasalahan penyesuaian diri juga ditemukan di Madrasah Aliyah Negeri (MAN) Sidoarjo yang merupakan salah satu sekolah MA sekaligus sekolah islam negeri satu-satunya di Kabupaten Sidoarjo. Dari situs web resmi MAN Sidoarjo menyatakan bahwa Madrasah Aliyah Negeri yang ada di Kabupaten Sidoarjo hanya ada satu dan yang lainnya swasta. Berdasarkan data awal yang diperoleh dari salah satu guru BK diketahui bahwa MAN ini memiliki siswa yang berasal dari berbagai sekolah baik lulusan Madrasah Tsanawiyah maupun lulusan Sekolah Menengah Pertama. Karena dari berbagai sekolah tersebut, para siswa dituntut untuk dapat beradaptasi dengan lingkungan baru. Selain itu, ada juga siswa MAN yang tinggal di Ma'had dan ada juga yang tidak. Permasalahan dengan guru, teman dan mata pelajaran, serta aturan yang berlaku di sekolah tersebut biasanya dialami oleh siswa dalam penyesuaian diri. MAN Sidoarjo memiliki fasilitas Al-Ma'had The Islamic Boarding School (pembinaan dalam bidang akademis dan keagamaan dengan metode asrama); laboratorium fisika, kimia, dan biologi; 4 (empat) laboratorium komputer; Prodistik (program setara diploma 1 bidang teknologi informasi) kerja sama dengan ITS; perpustakaan; masjid; aula; ruang kelas yang ber AC; MCK dan fasilitas kesehatan serta kelengkapan lain yang menunjang kebutuhan para siswa dalam menjalankan aktifitas di lingkungan sekolah (Najib, 2018).

Biasanya sekolah dimulai dari jam 06.45-14.30 WIB untuk hari senin hingga kamis, sedangkan jam 06.45-13.45 WIB untuk jum'at dan sabtu. Namun, ada hari dimana pembelajaran para siswa dimulai dari pukul 06.00 WIB untuk mata pelajaran BTQ. Untuk pembelajaran BTQ ini setiap tingkatan kelas berbeda. Seperti pelaksanaan pada hari senin dan kamis untuk kelas $X$, namun kelas XI dan XII di hari lain selain hari senin dan kamis. Untuk pelaksanaan upacara biasanya siswa dijadwalkan pada tanggal 1 dan 17 setiap bulannya. Peraturan dan tata tertib yang menjadikan siswa lebih disiplin, dan jadwal-jadwal yang runtut untuk para siswa dari awal sekolah dimulai hingga sekolah berakhir. Padatnya jadwal dan ketatnya peraturan di sekolah tersebut menyebabkan para siswa baru merasa kewalahan dan kurang bisa menyesuaikan diri dengan jadwal sekolah tersebut.

Dari komunikasi pribadi dengan guru Bimbingan dan Konseling diketahui bahwa siswa baru MAN Sidoarjo memiliki persoalan penyesuaian diri yang dapat diketahui misalnya dari siswa yang terlambat pada mata pelajaran BTQ karena pelaksanaannya pagi hari dan shalat dhuha berjama'ah, siswa yang mengumpulan tugas yang tidak tepat waktu, mencontek, dan permasalahan tata tertib atau aturan yang berlaku.

Fenomena penyesuaian diri ini selain terjadi di MAN Sidoarjo, juga telah terjadi di berbagai daerah. Hasil penelitian terdahulu yang dilakukan oleh Lathifah (2015), partisipan yang berjumlah 73 orang partisipan yang merupakan santri pondok pesantren Al-Luqmaniyyah Yogyakarta yang berstatus mahasiswa dengan hasil pengolahan data menunjukkan bahwa 75,6\% atau 55 remaja partisipan memiliki kategori penyesuaian diri yang tergolong tinggi. Selain itu, penelitian yang dilakukan oleh Lestari dan Indrawati (2017), penelitian ini melibatkan 183 orang partisipan yang merupakan siswa kelas VII Yayasan Pondok Pesantren Futurriyah Mranggen Kabupaten Demak. Dengan hasil pengolahan data yang menunjukkan bahwa skala religiusitas ( 27 aitem, $\alpha=0,894$ ) dan skala penyesuaian diri ( 28 aitem, $\alpha=0,845$ ). Hasil penelitian religiusitas dengan penyesuaian diri pada siswa $\left(r_{x y}=0,414, p=0,000\right)$. Religiusitas memberikan sumbangan efektif sebesar $17,1 \%$.

Penelitian lain yang dilakukan oleh Hidayat (2019), penelitian ini melibatkan 40 responden yang terdiri dari 20 siswa yang istiqomah melaksanakan shalat duha dan 20 siswa yang tidak istiqomah dalam melaksanakan shalat dhuha. Hasil dari pengolahan data menunjukkan bahwa $52,5 \%$ 
atau 21 responden memiliki kategori tinggi antara istiqomah melaksanakan shalat dhuha dengan penyesuaian diri.

Faktor yang dapat mempengaruhi penyesuaian diri dikelompokkan menjadi 2 (dua) kelompok, yaitu faktor internal dan eksternal (Soeparwoto, 2004). Faktor internal meliputi : motif, self-concept atau konsep diri, persepsi, sikap, intelegensi dan minat, serta kepribadian. Sedangkan faktor eksternal meliputi : keluarga, kondisi sekolah, kelompok sebaya, prasangka sosial, hukum dan norma. Salah satu faktor yang mempengaruhi penyesuaian diri adalah konsep diri. William H. Fitts menyatakan bahwa konsep diri ini merupakan aspek penting dalam diri seseorang, karena dalam berinteraksi dengan lingkungannya, kerangka acuan (frame of reference) seseorang merupakan konsep diri ( Agustiani, 2009). Tingkah laku seseorang dapat kita ketahui dan pahami dari konsep diri orang tersebut. Konsep diri terbentuk melalui berbagai pengalaman yang diperoleh dari interaksi dengan lingkungannya. Hereditas seseorang bukanlah faktor dari konsep diri, melainkan pengalaman yang terdiferensiasi dan berkembang secara berkelanjutan. Sedini mungkin dalam kehidupan anak, dasar dari konsep diri individu ditanamkan sehingga di kemudian hari dapat menjadi dasar yang mempengaruhi tingkah lakunya.

Konsep diri berperan dalam melakukan penyesuaian diri. Kemampuan dalam menyesuaikan diri dimiliki individu yang mempunyai konsep diri positif, sehingga terciptanya hubungan baik dengan orang-orang disekelilingnya. Sebaliknya, kesulitan dalam melakukan penyesuaian diri dialami oleh individu yang memiliki konsep diri salah, hal negatif akan mudah mempengaruhinya, juga bisa merugikan orang lain (Astutik, Astuti, \& Yusuf, 2016).

Hasil dari penelitian terdahulu mengenai penyesuaian diri maupun hasil wawancara yang diperoleh, baik pengalaman yang didapat di dalam dan diluar sekolah, penyesuaian memang sangat diperlukan. Penyesuaian diri ini sangat dibutuhkan terutama bagi siswa kelas X MAN Siodarjo, baik yang berasal dari MTS/SMP dikarenakan tidak semua murid tersebut bisa menyesuaikan diri dengan keadaan dan lingkungan barunya secara cepat. Berdasarkan fenomena tersebut, peneliti tertarik untuk menguji secara empirik tentang hubungan antara konsep diri dengan penyesuaian diri siswa kelas X MAN Sidoarjo. Hipotesis yang digunakan pada penelitian ini yaitu adanya hubungan positif antara konsep diri dengan penyesuaian diri.

\section{Metode Penelitian}

Penelitian ini memakai jenis kuantitatif korelasional dengan variabel penelitian konsep diri sebagai variabel bebas $(X)$ dan penyesuaian diri sebagai variabel tergantung $(Y)$. Studi kasus penelitian ini di Madrasah Aliyah Negeri Sidoarjo dengan subjek seluruh siswa kelas X (IPA dan IPS). Siswa kelas $X$ yang menjadi populasi dalam penelitian berjumlah 420 . Berdasarkan tabel penentuan jumlah sampel dari Isaac dan Michael (Sugiyono, 2015) dan dengan menggunakan taraf kesalahan $5 \%$, diperoleh sampel sebanyak 191 siswa. Teknik pengambilan sampel dengan accidental sampling. Pengukuran variabel dilakukan dengan menggunakan skala ordinal untuk penyesuaian diri dan konsep diri yang disusun berdasarkan metode Likert dengan empat pilihan jawaban. Subyek diminta memilih salah satu jawaban dari empat pernyataan yang menyatakan kesetujuan atau ketidaksetujuan yang sesuai dengan keadaan atau kondisi subyek antara lain sangat sesuai (SS), sesuai (S), tidak sesuai (TS), atau sangat tidak sesuai (STS) (Sugiyono, 2015). Pemberian skor skala ini bergerak dari angka empat (4) hingga satu (1) untuk aitem positif atau yang mendukung atribut yang 
diukur (favourable), sedangkan untuk skor aitem negatif atau pertanyaan yang tidak mendukung atribut yang diukur (unfavourable) bergerak dari 1 hingga 4. Sehingga dapat diperoleh nilai validitas skala aitem konsep diri memiliki nilai $r_{i x}$ dalam rentang 0,309-0,658 sedangkan nilai validitas skala penyesuaian diri memiliki nilai $r_{i x}$ dalam rentang $0,338-0,659$. Hasil koefisien reiabilitas skala konsep diri diperoleh nilai Alpha Cronbach's sebesar 0,900 dan untuk skala penyesuaian diri diperoleh nilai Alpha Cronbach's sebesar 0,882. Artinya koefisien reliabilitas mendekati angka 1, sehingga dapat dinyatakan sangat reliable. Pengambilan data dilakukan dengan menggunakan google form. Data penelitian dilakukan uji normalitas menggunakan uji Kolmogorof-Smirnov dan diperoleh bahwa data konsep diri berdistribusi normal $(p>0,05)$ sedangkan data penyesuaian diri berdistribusi tidak normal $(p<0,05)$. Uji linearitas menunjukkan kesimpulan bahwa variabel konsep diri dan penyesuana diri memiliki hubungan yang linear $(F=298,974, p<0.01)$. Teknik korelasi Non-parametrik dari Spearman digunakan sebagai teknik analisis data disebabkan oleh salah satu variabel yang tidak berdistribusi normal

\section{Hasil dan Pembahasan}

Sebaran data penelitian menghasilkan data deskriptif yang disajikan dalam tabel berikut ini:

Tabel 1. Deskripsi Data Penelitian

\begin{tabular}{cccccc}
\hline Variabel & N & Minimum & Maximum & Mean & Std. Deviation \\
\hline Konsep Diri & 191 & 68 & 112 & 91.32 & 8.334 \\
Penyesuaian Diri & 191 & 53 & 92 & 71.53 & 7.589 \\
Valid N (listwise) & 191 & & & & \\
\hline
\end{tabular}

Berdasarkan tabel di atas, pada skala konsep diri diperoleh nilai mean teoritik $(\mu)$ sebesar 91,32 dan deviasi standar $(\sigma)$ sebesar 8,334. Sedangkan pada skala penyesuaian diri diperoleh nilai mean teoritik $(\mu)$ sebesar 71,53 dan standar deviasi $(\sigma)$ sebesar 7,589. Adapun norma kategorisasi untuk skala konsep diri dan skala penyesuaian diri yaitu sebagai berikut.

Berdasarkan data tersebut, dilakukan kategorisasi sebaran sampel penelitian kedalam lima kategori yaitu sangat tinggi, tinggi, sedang, rendah, dan sangat rendah. Kategori dan sebaran sampel penelitian disajikan dalam tabel berikut ini:

Tabel 2. Kategorisasi Data

\begin{tabular}{|c|c|c|c|c|c|c|c|}
\hline \multirow{3}{*}{ Kategori } & \multirow{3}{*}{ Norma } & \multicolumn{6}{|c|}{ Skor } \\
\hline & & \multicolumn{3}{|c|}{ Konsep Diri } & \multicolumn{3}{|c|}{ Penyesuaian Diri } \\
\hline & & & ¿ Subjek & $\%$ & & $\sum$ Subjek & $\%$ \\
\hline $\begin{array}{l}\text { Sangat } \\
\text { Rendah }\end{array}$ & $x \leq(\mu-1,5 \sigma)$ & $\leq 79$ & 14 & $7,3 \%$ & $\leq 60$ & 16 & $8,4 \%$ \\
\hline Rendah & $(\mu-1,5 \sigma)<X \leq(\mu-0,5 \sigma)$ & $80-87$ & 46 & $\begin{array}{c}24,1 \\
\%\end{array}$ & $61-68$ & 34 & $17,8 \%$ \\
\hline Sedang & $\begin{array}{c}(\mu-0,5 \sigma)<X \leq(\mu+ \\
0,5 \sigma)\end{array}$ & $88-96$ & 85 & $\begin{array}{c}44,5 \\
\%\end{array}$ & $69-75$ & 69 & $36,1 \%$ \\
\hline Tinggi & $\begin{array}{c}(\mu+0,5 \sigma)<X \leq(\mu+ \\
1,5 \sigma)\end{array}$ & $97-104$ & 34 & $\begin{array}{c}17,8 \\
\%\end{array}$ & $76-83$ & 63 & $33 \%$ \\
\hline Sangat Tinggi & $\begin{array}{l}\qquad(\mu+1,5 \sigma)<X \\
\text { Jumlah }\end{array}$ & $>104$ & $\begin{array}{c}12 \\
191\end{array}$ & $\begin{array}{l}6,3 \% \\
100 \%\end{array}$ & $>83$ & $\begin{array}{c}9 \\
191\end{array}$ & $\begin{array}{l}4,7 \% \\
100 \%\end{array}$ \\
\hline
\end{tabular}


Berdasarkan uraian dari kategorisasi, dapat disimpulkan bahwa konsep diri siswa kelas $\mathrm{X}$ Madrasah Aliyah Negeri Sidoarjo termasuk dalam kategori sedang. Hal tersebut dapat diketahui dari persentase dan jumlah subjek pada tabel di atas, di mana mayoritas subjek memiliki skor dengan kategori sedang.

Hasil analisis data menunjukkan koefisien korelasi $r_{x y}=0,725$ dan signifikansi sebesar $p=$ 0,000 . Karena signifikansi $<0,05$, maka dapat disimpulkan bahwa hipotesis diterima, yang artinya terdapat hubungan positif antara konsep diri dengan penyesuaian diri. Hal tersebut berarti bahwa jika konsep diri positif, maka penyesuaian diri juga positif. Begitu juga sebaliknya, semakin negative konsep dirinya, maka semakain negative pula konsep dirinya.

Korelasi positif signifikan antara konsep diri dan penyesuaian diri pada siswa kelas X Sekolah Menengah Atas Islam Bawari Pontianak dengan nilai $r_{x y}=0,763$ yang dilakukan oleh Astutik, Astuti, dan Yusuf (2016) seuaia dengan penelitian ini. Artinya, konsep diri seseorang yang tinggi maka tinggi pula penyesuaian dirinya. Penelitian selanjutnya dilakukan oleh Saputri (2017), memperlihatkan terdapat hubungan positif signifikan antara konsep diri dengan penyesuaian diri pada siswa kelas $\mathrm{X}$ dengan $r_{x y}=0,668(p<0,01)$. Saputri (2017) juga menjelaskan bahwa penilaian dari individu tentang dirinya secara utuh sehingga mempunyai suatu keyakinan dan memperoleh hasil yang positif merupakan salah satu faktor untuk mencapai penyesuaian diri yang baik. Penelitian Gunawan, Jahada, dan Aspin (2019) menunjukkan hasil adanya hubungan positif dan signifikan antara konsep diri dengan penyesuaian diri siswa SMP Negeri 1 Napabalano. Hal ini dapat dilihat dari nilai $r_{\mathrm{xy}}=0,524$ yang artinya semakin tinggi konsep diri siswa maka semakin tinggi pula penyesuaian dirinya. Dasar terwujudnya penyesuaian diri siswa dalam lingkungan sekolah dan memeberikan sumbangan yang cukup berarti (sedang) merupakan konsep diri yang positif.

Berdasarkan uraian di atas, hasil penelitian ini konsisten dengan hasil penelitian sebelumnya, dimana terdapat hubungan positif antara konsep diri dengan penyesuaian diri. Hal tersebut berarti bahwa hubungan positif antara kedua variabel, yaitu konsep diri dengan penyesuaian diri dapat dikatakan konsisten untuk beragam populasi. Penelitian ini menunjukkan bahwa konsep diri memberikan sumbangan efektif sebesar $57,7 \%$ sebagai salah satu faktor internal, sedangkan $42,3 \%$ sisanya dipengaruh faktor lain yang tidak menjadi fokus penelitian ini.

Keluarga, keadaan sekolah, teman sebaya, praduga sosial, hukum dan norma adalah faktor eksternal dari pengaruh penyesuaian diri. seperti yang tercatat pada penelitian sebelumnya mengenai dukungan sosial teman sebaya dengan penyesuaian diri mahasiswa menunjukkan sumbangan efektif sebesar 33,9\% (Rufaida dan Kustanti, 2017), sedangkan penelitian lain mengenai kepuasan siswa terhadap kondisi lingkungan sekolah dengan penyesuaian diri santri pondok pesantren dengan sumbangsih yang diberikan sebesar 31,4\% (Islami, Hidayatullah, \& Erlyani, 2020)Hal tersebut menjelaskan bahwa konsep diri memiliki hubungan dengan penyesuaian diri. Kemampuan melakukan penyesuaian diri di lingkungan sekolah baru ialah konsep diri positif yang dimiliki sisiwa. Sehingga hal ini dapat menghindarkan siswa dari rasa frustasi, tidak nyaman sering terjadi konflik, dan sebagainya. Hal tersebut juga selaras dengan yang dikemukakan Fudyartanta (2012), yaitu faktor yang dapat mempengaruhi proses penyesuaian diri individu berasal dari dalam diri individu tersebut (internal) dan luar (eksternal) diri seseorang.

Hasil kategorisasi skor subjek dalam penelitian ini menunjukkan bahwa konsep diri siswa kelas X Madrasah Aliyah Negeri Sidoarjo termasuk dalam kategori sedang, sedangkan penyesuaian 
diri pada siswa kelas X Madrasah Aliyah Negeri Sidoarjo termasuk dalam kategori sedang. Ini menjelaskan bahwa terdapat konsep diri yang baik terhadap situasi dan lingkungan sekolah baru sehingga memungkinkan siswa untuk mempunyai penyesuaian diri yang baik.

Penelitian ini dapat membuktikan adanya hubungan positif antara konsep diri dengan penyesuaian diri pada siswa kelas X Madrasah Aliyah Negeri Sidoarjo. Namun penelitian sederhana ini tentunya tidak terlepas dari kekurangan, diantaranya yaitu terjadinya limitasi penelitian dimana skala pada penelitian ini terbatas hanya untuk populasi dan sampel dalam penelitian ini saja, sehingga tidak dapat di generalisasi dan membutuhkan modifikasi aitem. Selain itu, pengumpulan data dengan skala psikologi melalui google form, menyebabkan tidak ada pengawasan secara langsung oleh peneliti, sehingga memungkinkan subjek tidak bersungguh-sungguh dalam memberikan jawaban. Pengawasan yang tidak langsung dilakukan oleh peneliti juga membuat beberapa siswa yang telah melakukan pengisian uji coba skala dapat mengisi kembali skala penelitian meskipun peneliti sudah mencoba meminimalisirnya dengan melakukan pembatasan satu subjek hanya dapat mengisi 1 kali skalanya.

\section{Simpulan dan Saran}

Simpulan

Berdasarkan hasil penelitian dan juga pembahasan, dapat disimpulkan bahwa terdapat hubungan positif yang signifikan antara konsep diri dengan penyesuaian diri pada siswa kelas $X$ Madrasah Aliyah Negeri Sidoarjo. Siswa yang memiliki konsep diri yang baik, maka semakin baik pula penyesuaian dirinya.

\section{Saran}

Disarankan untuk siswa lebih bisa menyelesaikan masalah yang dialami dengan cara mencari bantuan kepada pihak yang dirasa dapat membantu seperti guru BK atau teman yang dipercaya mampu menyelesaikan masalahnya dengan baik. Sekolah dapat menggunakan hasil penelitian ini sebagai acuan dalam upaya membantu siswa dalam proses penyesuaian diri, misalnya membuat variasi kegiatan yang dapat mengakomodasi siswa agar lebih akrab antara satu dengan yang lain.

\section{Daftar Pustaka}

Astutik, W., dkk. (2016). Hubungan antara konsep diri dengan penyesuaian diri siswa kelas x SMA Islam Bawari Pontianak. Jurnal Pendidikan Dan Pembelajaran Untan.

Azwar, S. (2018). RELIABILITAS dan VALIDITAS (4th ed.). Yogyakarta: PUSTAKA PELAJAR.

Gunawan, R., dkk. (2019). Hubungan Konsep Diri Dengan Penyesuaian Diri Siswa SMP Negeri 1 Napabalano Kabupaten Muna. Bening, 3(2), 19-27.

Agustiani, Hendriati. (2009). PSIKOLOGI PERKEMBANGAN Pendekatan Ekologi Kaitannya dengan Konsep Diri dan Penyesuaian Diri pada Remaja (kedua; Drs. Dadi Pakar, Ed.). Bandung: PT. Refika Aditama. 
Hubungan Antara Konsep Diri Dengan Penyesuaian Diri Siswa Kelas X Madrasah Aliyah Negeri Sidoarjo

Proyeksi, Vol. 16 (1) 2021, 92-99

Hidayat, N. (2019). Pengaruh Pelaksanaan Salat Duha Secara Istiqomah Terhadap Penyesuaisn Diri Remaja. 52.

Islami, A., dkk. (2020). No Title. HUBUNGAN KEPUASAN SISWA TERHADAP KONDISI LINGKUNGAN SEKOLAH DENGAN PENYESUAIAN DIRI SANTRI PONDOK PESANTREN DARUL HIJRAH PUTERA MARTAPURA. Retrieved from http://ppjp.ulm.ac.id/journals/index.php/kog/article/view/1449

Santrock, John W. (2012). LIFE SPAN DEVELOPMENT PERKEMBANGAN MASA-HIDUP (Ketigabela; Novietha I. Sallama, Ed.). Jakarta: Erlangga.

Kaplan, H. I., dkk (1997). Sinopsis Psikiatri : Ilmu Pengetahuan Perilaku Psikiatri Klinis (Jilid 2). Jakarta: Binarupa Aksara.

Ki Fudyartanta. (2012). Psikologi Kepribadian. Yogyakarta: Pustaka Pelajar.

Kuswono. (2013). PENDIDIKAN KARAKTER POLA MUHAMMADIYAH (Studi Kasus SMA Muhammadiyah 1 san MA Muallimn Yogyakarta). Guidena, 3(1), 43-49.

Lestari, D., \& Indrawati, E. S. (2017). Hubungan Antara Religiusitas Dengan Penyesuaian Diri Pada Siswa Dan Siswi Kelas Vii Yayasan Pondok Pesantren Futuhiyyah Mranggen Kabupaten Demak. Jurnal Empati, 6(4), 307-312.

Madrasah Aliyah. (2018). Retrieved from KANWIL KEMENAG DKI website: https://dki.kemenag.go.id/unit-kerja-madrasah-aliyah

Najib, M. A. (2018). Madrsah Aliyah Negeri Sidoarjo. Retrieved from MAN SIDOARJO website: https://www.mansidoarjo.sch.id/about/

R, L. N. N., \& Christiana, E. (2015). Penanganan Konselor Terhadap Masalah Penyesuaian Diri Siswa SMA Negeri 3 Tuban. BK Unesa, 05, 9-18. Retrieved from https://jurnalmahasiswa.unesa.ac.id/index.php/jurnal-bk-unesa/article/view/10155

Rufaida, H. R., \& Kustanti, E. R. (2017). Hubungan Antara Dukungan Sosial Teman Sebaya Dengan Penyesuaian Diri Pada Mahasiswa Rantau Dari Sumatera Di Universitas Diponegoro. Empati, 6(3), 217-222.

Saputri, B. A., Psikologi, F., \& Soegijapranata, U. K. (2017). PENYESUAIAN DIRI PADA PESERTA DIDIK KELAS X SMK.

Soeparwoto. (2004). Psikologi Perkembangan. Semarang: UPT MKK UNNES.

Sugiyono. (2015). METODE PENELITIAN KUANTITATIF KUALITATIF DAN R\&D. Bandung: ALFABETA BANDUNG. 